\title{
Peer Influence in Network Markets: An Empirical Investigation
}

\author{
Jörn H. Block and Philipp Köllinger
}

\begin{tabular}{|l|l|}
\hline \multicolumn{2}{|l|}{ ERIM REPORT SERIES RESEARCH IN MANAGEMENT } \\
\hline ERIM Report Series reference number & ERS-2007-063-ORG \\
\hline Publication & September 2007 \\
\hline Number of pages & 43 \\
\hline Persistent paper URL & \\
\hline Email address corresponding author & koellinger@few.eur.nl \\
\hline Address & Erasmus Research Institute of Management (ERIM) \\
& RSM Erasmus University / Erasmus School of Economics \\
& Erasmus Universiteit Rotterdam \\
& P.O.Box 1738 \\
& 3000 DR Rotterdam, The Netherlands \\
& Phone: $\quad+31104081182$ \\
& Fax: $\quad+31104089640$ \\
& Email: info@erim.eur.nl \\
& Internet: $\quad$ www.erim.eur.nl \\
\hline
\end{tabular}

Bibliographic data and classifications of all the ERIM reports are also available on the ERIM website: www.erim.eur.nl 


\section{ERASMUS RESEARCH INSTITUTE OF MANAGEMENT}

\section{REPORT SERIES \\ RESEARCH IN MANAGEMENT}

\begin{tabular}{|l|l|}
\hline ABSTRACT AND KEYWORDS \\
\hline Abstract & $\begin{array}{l}\text { We analyze the effect of peer influence on the diffusion of an innovative network good. We argue } \\
\text { that the adopters of a network good have an incentive to convince others to purchase the same } \\
\text { product because their utility depends on the number of other users. This peer-effect influences } \\
\text { individuals' adoption decisions alongside the more familiar installed-base-effect, based on the } \\
\text { individual's own insight that a larger number of installed units increases his/her benefit of } \\
\text { adopting. We test empirically which effect dominates with Instant Messaging, an innovative } \\
\text { network good. We arrive at surprising results with far-reaching implications for research and } \\
\text { management. The diffusion of Instant Messaging was to a large extent driven by the peer-effect, } \\
\text { but the installed-base-effect seemed to play no role. We perform our estimation with a discrete } \\
\text { time hazard rate model that controls for unobserved heterogeneity. }\end{array}$ \\
\hline Free Keywords & Innovation Diffusion, Peer Influence, Network Markets, Hazard Rate Model, Instant Messaging \\
\hline Availability & $\begin{array}{l}\text { The ERIM Report Series is distributed through the following platforms: } \\
\text { Academic Repository at Erasmus University (DEAR), DEAR ERIM Series Portal } \\
\text { Social Science Research Network (SSRN), SSRN ERIM Series Webpage } \\
\text { Research Papers in Economics (REPEC), REPEC ERIM Series Webpage }\end{array}$ \\
\hline Classifications & $\begin{array}{l}\text { The electronic versions of the papers in the ERIM report Series contain bibliographic metadata } \\
\text { by the following classification systems: } \\
\text { Library of Congress Classification, (LCC) LCC Webpage } \\
\text { Journal of Economic Literature, (JEL), JEL Webpage } \\
\text { ACM Computing Classification System CCS Webpage } \\
\text { Inspec Classification scheme (ICS), ICS Webpage }\end{array}$ \\
\hline
\end{tabular}




\title{
Jörn H. Block/Philipp Köllinger*
}

\section{Peer Influence in Network Markets: An Empirical Investigation**}

\begin{abstract}
:
We analyze the effect of peer influence on the diffusion of an innovative network good. We argue that the adopters of a network good have an incentive to convince others to purchase the same product because their utility depends on the number of other users. This peer-effect influences individuals' adoption decisions alongside the more familiar installed-base-effect, based on the individual's own insight that a larger number of installed units increases his/her benefit of adopting. We test empirically which effect dominates with Instant Messaging, an innovative network good. We arrive at surprising results with far-reaching implications for research and management. The diffusion of Instant Messaging was to a large extent driven by the peer-effect, but the installed-base-effect seemed to play no role. We perform our estimation with a discrete time hazard rate model that controls for unobserved heterogeneity.
\end{abstract}

JEL-Classification: M3, D12, O32.

Keywords: Innovation Diffusion; Peer Influence; Network Markets; Hazard Rate Model; Instant Messaging.

* Jörn H. Block (corresponding author), Ph.D. candidate, Technische Universität München, Dr. Theo Schöller Chair in Technology and Innovation Management, Arcisstr. 21, D-80333 Munich, Germany, telephone: +498928925746, e-mail: block@wi.tum.de; Philipp Köllinger, Assistant Professor, Erasmus University Rotterdam, Campus Woudestein, Burgemeester Oudlaan 50, 3062 PA Rotterdam, The Netherlands, e-mail: koellinger@few.eur.nl, and Humboldt-Universität zu Berlin, Institute for Entrepreneurial Studies and Innovation Management as well as DIW Berlin, Germany. 
** We would like to thank Oliver Alexy, Andrei Anissimov, Joachim Henkel, Werner Kunz, Christian Schade, Juliane Scheffel, Andrew Smith, Marcus Wagner, Hendrik Wermer, an anonymous reviewer, and participants of the CEFS-ODEON seminar in Munich for valuable comments and suggestions. This study is developed from the diploma thesis of Jörn H. Block at Christian Schade's Institute for Entrepreneurial Studies and Innovation Management at Humboldt-Universität zu Berlin. All errors are ours. 


\section{Peer Influence in Network Markets: An Empirical Investigation}

\section{Introduction}

With the increasing diffusion of modern information and communication technologies, network markets have become an omnipresent phenomenon. Innovations such as email, online auctions, and file sharing exhibit network externalities and play an important role in today's economy. The economics literature offers a well-founded theory of network goods. Examples include Besen/Farrel (1994), David (1985), Farrel/Saloner (1986), Katz/Shapiro (1985; 1986; 1992) and Liebowitz/Margolis (1994). In this paper, we refer to this theory of network goods and relate it to studies about peer influence, a concept from the field of sociology or social psychology (see, e.g., Cialdini/Trust 1998).

In network markets, the utility that a consumer derives from consumption of the good increases along with the number of other individuals consuming the good (Katz/Shapiro 1985), a phenomenon commonly referred to as network externalities. In this paper, we establish and empirically test a theory that disentangles the two mechanisms by which these network externalities drive the diffusion of an innovative network good. The first mechanism builds on the individual's own insight that his/her benefit increases with a larger number of installed units. An individual would adopt an innovative network good if the number of installed units were large enough to create a substantial benefit. Those individuals already in the network matter only insofar as they increase the number of installed units. We name this mechanism installed-base-effect. The second mechanism works such that those who have already adopted the network good have an incentive to persuade others to also adopt the network good, because their own utility depends strongly on their peers being in the network. With this mechanism, the individual's own insight that a large network creates substantial benefits is of less importance. The individual adopts the network good, because 
peers exert influence on the adoption decision. We label this mechanism peer-effect.

A clear separation of these two mechanisms helps us to better understand how an innovative network good is diffused. It also has practical value for marketing managers, for whom network externalities may play an important role. If, for example, network externalities are present in a market dominated by a large incumbent, a potential entrant into this market must take this fact into account. Absent an installed base, a potential customer faces substantial disadvantages with the entrant's product compared to the incumbent's. The entrant is obliged to offer compensation. For example, the entrant might offer a price discount to early adopters of the new standard or make her products available on a rental basis (Liebowitz/Margolis 1990). Another strategy is to achieve compatibility with the incumbent's product (Besen/Farrel 1994).

In this paper we argue for a different approach. As we demonstrate, peer influence constitutes an important factor influencing the decision whether to adopt a network good. Therefore, a successful market entry strategy might be to count on peer influence to stimulate the diffusion of a new network product. For example, the entrant might advertise the product in a way that favors peer influence (e.g., Pechmann/Knight 2002) or might offer a bonus for those customers who successfully attract new customers.

Our research design is as follows. We developed a questionnaire that measured the level of peer influence and the impact of the installed base with regard to the adoption of an innovative network product and conducted a survey $(\mathrm{N}=470)$. The aim of the survey was to measure the impact of the peer- or the installed-base-effect on the adoption and diffusion of an innovative network good, Instant Messaging (IM). We analyzed the data using hazard rate models. 
Our study extends the literature in various aspects. (1) We develop a conceptual framework to investigate how network externalities and peer influence interact with each other. In particular, we provide a rationale to explain why individuals might influence their peers to adopt a particular network good. (2) We develop new scales to measure the impact of the installed base as well as the degree of peer influence. (3) For the adoption and diffusion of Instant Messaging our empirical evidence shows that peer influence has a stronger impact than does the more familiar installed-baseeffect. For Online Banking, a comparable innovation without network externalities, this peer-effect seems to play no role. (4) We discuss the marketing implications of our findings and suggest a set of possible market entry strategies into network markets.

The paper is organized as follows: Section 2 briefly reviews the literature about network externalities and peer influence, and relates it to our research question. Section 3 describes Instant Messaging, the innovation covered in the survey. Section 4 lays out our hypotheses. Section 5 describes the data set and the methods used in the empirical study. Section 6 reports the results. Section 7 discusses our results as well as the study's limitations and provides some ideas for further research. Section 8 points out marketing implications.

\section{Theoretical Framework and Existing Literature}

\section{$2.1 \quad$ Network Externalities}

The first articles in the field of network economics were inspired by the U.S. federal antitrust agency's controversial decision to break up AT\&T, by then the largest company in the world. Katz/Shapiro (1985) took up this case and developed a theory about the interrelation between network products and market competition. They differentiated between direct and indirect network externalities. If the number of users of a particular product has a direct influence on the value of the product, then direct network external- 
ities are present (e.g., in the case of the fax or the telephone). In contrast, if the quality of the product is influenced by the diffusion of another product, then indirect network externalities prevail (e.g., the relation between computer hardware and computer software). Inspired by Katz/Shapiro (1985), two approaches and two strands of mainly theoretical studies developed (Economides 1996). The first strand, which uses a macro approach, assumes network externalities as given and models their consequences on competition, market entry, technology adoption, etc. Examples are articles by Katz/Shapiro $(1986 ; 1992)$, which study technology adoption or product introduction in the presence of network externalities. The second group of studies addresses the specific microstructure of a network. It uses the perspective of a producer of a network good and deals with questions of compatibility and coordination (e.g., Besen/Farrell 1994)

On the empirical side, there are two main ways to measure direct network externalities (Clement 1999): studies that measure direct network externalities by means of hedonic pricing (e.g., Brynjolfson/Kemerer 1996; Gandal 1994), and studies that measure direct network effects by the size of the installed base (e.g., Kim/Kwon 2003; Saloner/Shepard 1995; Shankar/Bayus 1997). Our study differs, in that it represents an attempt to measure the effects of network externalities on the micro-level. However, our aim is not to measure the degree of direct network externalities in itself, but to focus on its impact on technology adoption in the form of the two mechanisms introduced above, the installed-base- or the peer-effect.

\subsection{Peer Influence}

The concept of peer influence focuses on the relationship between the adopter and his/her social environment. When individuals are together in groups, they exercise influence on each other (Cialdini/Trust 1998). There are two competing perspectives on how peer influence affects an individual's behavior. An individual might agree with another individual's opinion 
because he or she was persuaded by the arguments (informational influence) or because he or she concedes to some kind of social pressure (normative influence) (Cialdini/Trust 1998). Peer influence as a concept is discussed in a variety of disciplines including sociology, psychology, and consumer behaviour research. Yet, to the best of our knowledge, the concept has not been applied to the adoption of network goods. Our purpose is to find out about the influence that peers might exert on an individual that has not yet adopted a particular network good, Instant Messaging.

On a conceptual basis, peer influence is related to and partially overlaps with peer pressure, word-of-mouth effects, and social contagion. Unfortunately, these concepts are not used in a consistent way in either the literature or across different disciplines. Therefore, some further clarifications and explanations appear necessary to describe what exactly we aim to measure in our study.

Peer pressure: Peers might persuade an individual to behave in a way in which he originally did not intend to (e.g., the individual starts to smoke which he would otherwise not have started). This behavior is referred to as peer pressure and can be broken down into a "good" and a "bad" type. With "bad" peer pressure, the individual is coerced to act against her own will, but with "good" peer pressure she is pushed into something she either did not have the courage to do or simply had not thought about. The distinction draws on the following: with "good" peer pressure, the individual perceives her action - at least from an ex-post perspective - as a good thing to do, while with "bad" peer pressure this is not the case. However, we note that the meaning of peer pressure differs substantially, according to the discipline concerned: in sociology, the term is mainly used in its negative connotation. Some sociological studies analyse the impact of peer pressure on smoking, drug, and alcohol use (e.g., Halebsky 1987; Melby et al. 1993). In some economics studies, peer pressure is regarded as a way to overcome the free-rider problem associated with teams (e.g., Falk/Ichino 2006; Kan- 
del/Lazear 1992). Peer pressure serves here as a motivational device, deterring the individual to shirk on her fellow team members, which is, at least from a welfare perspective, something positive.

For our study, we do not know about the original motivation of the potential adopter. In particular, we do not know whether she originally wanted to adopt the network good or not, and whether or not she later found that the adoption decision was beneficial. Since our primary interest is in understanding the drivers of the adoption decision rather than the consequences for each individual, we speak of peer influence rather than peer pressure, because peer influence has a less judgmental connotation.

Word-of-mouth: The effect of peer influence must be separated from wordof-mouth communication. The latter concerns a communication channel; peer influence is about interpersonal influence. Some innovation diffusion models differentiate between mass-media communication and communication by word-of-mouth. These models assume that the former mainly affects early entrants (the innovators), but that the latter impacts only later entrants (the imitators). For an example, see Tanny/Derzko (1988) in their extension of the model by Bass (1969). With word-of-mouth communication, information is passed by verbal means in an informal way from person to person, rather than by mass media such as radio, television, or newspapers (Rogers 2003, 205). Word-of-mouth communication is central for interpersonal influence (e.g., Mahajan et al. 1990). Therefore, peer influence is likely to happen by word-of-mouth communication, but not every informal interpersonal communication will result in peer influence.

Social contagion: The idea of social contagion, which is prominent in the (sociological) innovation diffusion literature, is related, but not equivalent, to the concept of peer influence. In its most general sense, social contagion means that the behavior of a potential adopter is a function of another actors' knowledge, attitude, or behavior concerning the innovation (Van den 
Bulte/Lilien 2001). The idea of social contagion was originally brought forward by Coleman et al. (1966) in their classic study on the diffusion of tetracycline, an antibiotic drug. Inspired by this landmark study, researchers have offered different causal mechanisms of social influence, among which are information transfer, normative pressures, and network effects. The argument about information transfer basically concerns an update of beliefs about an innovation's costs and benefits. Witnessing another person's adoption behavior conveys significant information. The potential adopter not only becomes aware of the innovation itself, but also learns about the consequences of its adoption. In this way, a person's social network influences the diffusion of an innovation in a social system (for a prominent example, see Chatterjee/Eliashberg 1990). The other two explanations - normative pressures and network effects - directly relate to the content of our study. Normative pressures concern the peer effect, and network effects concern the installed-base-effect. In a nutshell, the concept of social contagion offers many more causal mechanisms than just peer influence and network externalities, the two concepts we analyze.

In our study, we want to find out whether a not-yet-adopter of a particular network good is drawn into the network by his peers and how this effect compares to the installed-base-effect. We do not investigate whether the peers exert their influence by means of word-of-mouth or whether the notyet-adopters perceive this influence as "good" or "bad."

Because we discuss the marketing implications of our findings (see section 8), below, we sketch some particular pieces of research from the consumer behavior literature. In this literature, peer influence is mentioned in several ways. Bearden/Etzel (1982) categorize goods along two dimensions: first, according to whether they are commodities or luxury goods, and second, according to whether they are consumed in public or in private. Bearden/Etzel (1982) show that the strongest degree of peer influence takes place in the category of luxury good/consumption in public, and the weak- 
est degree of peer influence occurs in the category of commodity/consumption in private. In a replication and extension of Bearden/Etzel's (1982) study, Childers/Rao (1992) show that the influence of various reference groups varies with product type. A familial reference group has a greater impact on the consumption decision of privately consumed goods, and a peer-based reference group mainly influences consumption decisions of publicly consumed goods. It seems that family members have greater influence in situations in which peers have less influence, and vice versa. Other recent studies on peer-based group influence on purchase decisions are, e.g., Luo (2005) and Mangleburg et al. (2004).

\section{The Innovation in the Survey: Instant Messaging}

Instant Messaging, as we know it today, was invented in 1996 by four Israeli programmers, who started ICQ, an acronym for "I seek you." Today, Instant Messaging is a popular form of communication on the Internet. In 2004, more than 53 million U.S. adults were reported to use Instant Messaging regularly (Shiu/Lenhard 2004). The market for Instant Messaging is dominated by three big players: AOL, which also owns ICQ, Yahoo!, and Microsoft's MSN. None of these companies currently makes any money with Instant Messaging. However, the technology is regarded as crucial, since it is one vehicle for Internet telephony (The Economist 2005). Instant Messaging allows for real-time communication between its users. A user can send messages to anyone on his contact list and the message pops up immediately on the other user's computer screen. But in order to exchange messages, both users have to be members of the same network (e.g., the AOL or MSN network). Thus, we expect Instant Messaging to exhibit strong direct network externalities. Instant Messaging is virtually free of charge. Any person can register for free with ICQ, MSN or any other Instant Messaging service. 
To support informal communication among co-workers, firm-internal Instant Messaging services are installed in many workplaces. The main advantages of Instant Messaging are its speed, the brevity of its messages, and characteristics that promote multitasking (Isaacs et al. 2002). However, in this paper, we concentrate on the social use of Intant Messaging, e.g., keeping in touch with friends (Nardi et al. 2002).

Technically, Instant Messaging resembles a star network (e.g., Economides 1996). The service provider maintains a server, and all members of the Instant Messaging network log in to this main server. If two members of the network want to communicate with each other, they must be logged in to the server at the same time. For Instant Messaging to be of any value, there should be at least two persons logged in simultaneously. Therefore, we can perceive Instant Messaging as a network good. 


\section{$4 \quad$ Hypothesis Development}

Assume that a consumer adopting a network good has gross benefits of $u(N)$ and net benefits of $u(N)$-p, where $N$ denotes the number of network members, and $p$ describes the price. To exhibit positive direct network externalities, $N$ must be greater than one and the following equation must hold:

(1) $\frac{\partial u(N)}{\partial N}>0$.

The consumer's utility increases along with the size of the network $(N)$. Thus, as long as her marginal benefit of having a larger network exceeds her marginal cost of persuading a friend to join, then each consumer in the network has a strong incentive to persuade another person to join the network. We assume the consumer's marginal benefit from a new network member to decrease in $N$, i.e., $u_{N N}<0$. For the adoption and diffusion of a network good, the following statement should be true:

If positive direct network externalities prevail, then peer influence should arise and, ceteris paribus, stimulate the adoption and diffusion of a network good (peer-effect).

The source and the intensity of peer influence should change along with the diffusion of the network good. In the beginning, when only few people are in the network, the benefit from attracting new network members should be greater than at a later stage. Thus, we should observe intensive peer influence exerted by a small number of people. At a later stage, the situation should be different. The marginal benefit of attracting new network members is small, leading to a lower level of peer influence than at the earlier stage. On the other hand, the network community is larger than at the beginning, and more network members might exert influence. 
As denoted in equation (1), with network goods, the consumer's utility depends on the size of the network $(N)$. A larger utility from consuming the product should in turn have a positive impact on the adoption decision. Thus, there should also be a direct link between network externalities and adoption behavior. The following should hold:

If positive direct network externalities prevail, then the utility from consuming the good increases with its installed base. A higher utility should in turn stimulate the further adoption and diffusion of the good (installed-base-effect). 
Figure 1 conceptualizes the mechanisms described above.

\section{Insert figure 1 about here.}

Given this conceptual framework, we derive two hypotheses related to our survey.

Following our general statement on the interrelation between network externalities and peer influence, and the resulting peer-effect, peer influence should be crucial to the adoption of a network good. Therefore, if the participants perceive Instant Messaging as a network good, hypothesis 1 should hold.

Hypothesis 1: The propensity to adopt Instant Messaging increases with a higher level of peer influence (peer-effect).

For the installed-base-effect of network externalities and the adoption or diffusion of Instant Messaging, we formulate hypothesis 2:

Hypothesis 2: The propensity to adopt Instant Messaging increases with a higher level of perceived direct network externalities (installed-base-effect).

We do not explicitly formulate the question of whether the one or the other effect dominates as a hypothesis, but it is nevertheless of great interest, since it has important implications on marketing strategy.

\section{Empirical Study}

\subsection{Data}

To test our hypotheses, we conducted an online survey with altogether 470 participants. The survey took place between the $25^{\text {th }}$ of December 2004 and the $16^{\text {th }}$ of January 2005 . The sample is biased towards young age groups, which is explained by the fact that mostly students were asked. However, 
this bias should only be a minor problem, since the user community for Instant Messaging is also very young (Shiu/Lenhard 2004). For a more detailed description of the survey's participants, see table A1.

Our questionnaire was of a retrospective type, meaning that the participants were asked to answer the questions from the perspective of the moment when they decided about whether or not to adopt Instant Messaging. In particular, the participants were asked whether they adopted the innovation and, if applicable, in which year they did so. Those who did not know about the innovation concerned were directed to the questions concerning the background of the individual. The constructs were operationalized by means of single- and multi-item measures, where we used a 6-point Likert scale ranging from "strongly disagree" (1) to "strongly agree" (6). ${ }^{1}$ The operationalization is displayed in detail in table A4. With this retrospective survey, we created an unbalanced pseudo-panel data set.

To find out whether the participant perceived the size of the installed base (i.e., the number of individuals who have already adopted) as important, she was asked to answer the following statement:

\section{Insert table 1 about here}

With regard to peer influence, the participants were asked to evaluate a statement concerning the influence of their social network at the moment when they decided about the adoption. If they were inspired, invited, or

\footnotetext{
${ }^{1}$ We entered the multi-item measures into the hazard rate model as index variables (mean of corresponding items). We did not enter factor analysis scores, since doing so would make a comparison with the single-item measures difficult. The Cronbach $\alpha$-values that we calculate nevertheless indicate the constructs' internal consistencies (table A4).
} 
even pressured by their friends to register, a high degree of peer influence was at work. The following item was used: ${ }^{2}$

\section{Insert table 2 about here.}

As control variables, we included questions about the following constructs:

- Variables inseparably linked with the innovations concerned such as the Rogers criteria (perceived original benefit, perceived compatibility, perceived complexity, perceived trialability and perceived communicability of the innovation; Rogers 2003, 15-16), the perceived risk attached to the innovation (Bauer 1960), and variables capturing possible indirect network externalities between the innovation and other related products. ${ }^{3}$

- Variables linked to the personality of the participant, such as her desire to be innovative, psychographic attributes (opinion leadership) as well as various socio-demographic variables (gender, age, occupation, etc.).

${ }^{2}$ In addition, we included an item related to word-of-mouth communication into the questionnaire and found it to be strongly correlated with the item related to peer influence $(r=0.69)$. This is consistent with the view that peer influence is most likely to occur due to word-of-mouth communication. In order to separate word-of-mouth effects from peer influence, we excluded the word-of-mouth construct from the regression. However, the results reported below do not qualitatively change if word-of-mouth effects are included in the peer-effects construct.

${ }^{3}$ To control for indirect network effects, we asked the participant to name which other Internet-applications she uses (online auctions, file sharing, etc.). 
In several aspects our questionnaire resembles the questionnaire of Litfin (2000), who studied the adoption and diffusion on an innovative telecommunication service. Our questionnaire (in German) is available from the corresponding author.

\subsection{Method}

To study the individual duration until the adoption, we estimate a hazard rate model. Because our survey measures duration until adoption in discrete time intervals (years), we specify a discrete time model. In addition, given that diffusion processes can best be described by a logistic function (Griliches 1957; Stoneman 2002), we assume that the cumulative distribution of all adoption decisions over time is logistic. We specify duration dependence as flexible piecewise constants (DURAT1-DURAT10). Doing so implies that we do not need to assume that all individuals will adopt the innovation as time approaches infinity. To estimate the model, we follow Jenkins (1995) and take advantage of the close relation between generalized linear models and discrete time hazard rate models. Technically, we perform the estimation with STATA's xtlogit command, which we apply to the survey data reorganized in person-period format. ${ }^{4}$

We are interested in the probability of the participant exiting the status of non-adopter at $t$, given that he did not adopt until $t$ (hazard rate). We specify the discrete time hazard rate function as

(2) $\quad h(v \mid X)=\frac{1}{1+\exp \left(-\alpha_{v} \theta_{v}-\overline{\beta X}-\delta_{i}\right)}$,

\footnotetext{
${ }^{4}$ The data-file as well as the STATA ${ }^{\circledR} \log$-file can be requested from the corresponding author.
} 
where $h(v \mid X)$ is the hazard rate in period $v$ with $t_{v-1} \leq t<t_{v}$ for $v=2, \ldots, V, \theta_{v}$ is a vector of dummy variables such that $\theta_{v}=1$ if $t_{v-1} \leq t<t_{v}$ and $\theta_{v}=0$. Otherwise, $\alpha_{v}$ is the period-specific baseline hazard rate. $\beta$ denotes the parameter vector relating to the individual vector of covariates $X$, and $i=1, \ldots, N$ denotes individuals in the sample.

The individual level error component $\delta_{i}$ controls for the potential influence of unobserved individual characteristics on the hazard rate. Following the usual conventions, we model random individual effects and assume that $\delta_{i}$ is normally distributed with zero mean and independence of $\delta_{i}$ with all observable characteristics. Conveniently, this model also allows us to measure the extent to which unobserved individual characteristics influence the timing of adoption decisions. The relative importance of $\delta_{i}$ is measured as $\rho=\sigma_{\delta}^{2} /\left(\sigma_{\delta}^{2}+1\right)$, which is the proportion of the total unexplained variance contributed by individual-specific effects (Wooldridge 2002).

\section{$6 \quad$ Results}

Table 3 reports the results of the hazard rate analysis. Table A2 displays the correlations between the covariates. After excluding all observations with missing values, we obtain a sample size of 370 . The final estimation sample consists of 282 adopters and 88 non-adopters. The adoption curve peaked in the year 2000, which is consistent with the findings of other studies. $^{5}$

We find no significant unobserved individual effects in the hazard rate regression (table 3), i.e. $\rho$ is not significantly different from zero. Hence, the

\footnotetext{
${ }^{5}$ Köllinger $(2003$, 480) reports the number of new Internet users in Germany to peak between 2000 and 2001. Internet access is a prerequisite for Instant Messaging.
} 
timing of adoption decisions in the sample is comprehensively explained by the observed variables. ${ }^{6}$ The data analyses yield the following results:

\section{Insert table 3 about here.}

\section{Hypothesis 1: Peer-effect of Network Externalities}

There exists peer influence with Instant Messaging, and this influence varies considerably across the participants of the survey. The respective item has a mean of 3.35 (table A4), showing that the group of adopters has a statistically significant higher mean (3.75) than does the group of nonadopters (1.91) (table A3). ${ }^{7}$ Peer influence has a strong impact on the diffusion of instant messaging.

Hypothesis 1 is confirmed by econometric results. The $\beta$-coefficient in the hazard rate model is 0.198 with $\mathrm{p}<0.01$ (table 3 ). According to this result, a higher degree of peer influence has a positive impact on the participant's hazard rate, i.e., her probability of exiting the status of non-adopter at $t$, given that she did not adopt until $t$. This result is in line with other qualitative evidence. For example, Grinter/Palen (2002) find that Instant Messaging communications are "mostly restricted to one's 'real space friends' and that its adoption is best described as group wise".

\footnotetext{
${ }^{6}$ Thus, the remaining unexplained variance is purely random and not due to omitted variables.

${ }^{7}$ A two-sided t-test about the equality of means is rejected with $\mathrm{p}<0.001$.
} 


\section{Hypothesis 2: Installed-base-effect of Network Externalities}

The results of the hazard rate analysis do not support hypothesis 2 . The $\beta$ coefficient in the hazard rate model is statistically nonsignificant at -0.097 (table 3). Hence, it seems that the expectations about the installed base (table 1) did not have a decisive influence on the adoption decision. This result is surprising, but it accords with the findings of Litfin $(2000,306)$, who does not find an adoption stimulating influence of the size of the installed base on the diffusion of an innovative telecommunication service. It seems that the impact of network externalities on the diffusion of a network good is not as straightforward as some articles from the field of network theory suggest (e.g., Katz/Shapiro 1986; 1992).

In a nutshell, the peer-effect clearly dominated the installed-base-effect. The participants were pulled into the network by their friends, rather than adopting it just because of their own insight that a larger network would offer them a greater benefit.

We tested our theory and our operationalization of the two effects by applying the same questionnaire to a comparable non-network product, Online Banking (see table A5). In this case, we could find no impact of peer influence, providing further evidence for our theory about the interrelation between network externalities and peer influence.

\section{Impact of Control Variables}

The inclusion of the control variables yields some interesting results: the perceived risk attached to the adoption of Instant Messaging seemed to play an important role. The $\beta$-coefficient in the hazard rate model is -0.41 with $\mathrm{p}<0.001$ (table 3). It seems that worries about being affected with a computer virus, problems of data protection, or distraction from other things caused individuals to adopt Instant Messaging at a later point in time. The original benefit of Instant Messaging (e.g., its speed) seemed to have no impact on the adoption decision, which supports the idea of Instant Mes- 
saging being a network good. Furthermore, the perceived degree of the effectiveness of the innovation's trialability, the participant's innovativeness, and the degree of indirect network externalities seemed to have an adoption-stimulating impact, but a higher age seemed to hinder adoption. We find that the degree of opinion leadership has no significant impact on the adoption decision. 


\section{Discussion, Limitations, and Further Research}

We find empirical support for our theory claiming that peer influence constitutes an important factor in the adoption of an innovative network good, because the users of a network good have an incentive to convince others to purchase the same product, given that their utility depends on the number of other users. This peer influence turns out to have a stronger impact on adoption decisions than does the installed-base-effect, based on the individual's insight that a larger number of users increases her benefit. Also, we find that peer influence had no significant influence on the adoption decision of a comparable innovation without network effects. This finding suggests that in some cases, the degree of peer influence on the adoption decisions can be partially explained by network externalities.

Our paper contributes to the literature by providing a conceptualization about the interrelation between network externalities and peer influence, by developing and testing scales measuring the two constructs, and by providing a straightforward explanation of peer influence in network markets. From the perspective of the practitioner, the findings have important implications for marketing strategy (see section 8).

Our empirical research design suffers from two limitations. First, we estimated our models with a pseudo-panel data set generated through a retrospective survey. Retrospective surveys depend crucially on the participant's memory, which might sometimes bias the results (Schnell et al. 2005, 233). Second, the covariates are time-invariant. The reason is that pre-test interviews showed that the participants were not able to answer the questions in a time-variant manner.

Further research seems warranted to investigate how network externalities and peer influence interact with each other. In this context, potential research questions could be: What is the personality of the person who exerts peer influence? What is the personality of the person who is susceptible to 
peer influence? How can a person be motivated to exert peer influence stimulating the diffusion of a particular network product? Because we assume that the innovation-decision process occurs in stages, at what stage does peer influence interfere?

It would also be interesting to learn more about the impact of peer influence on adopting other network goods such as internet telephony or a membership in a sports club. From a model-theoretical perspective, it might be interesting to develop a model about the interrelation between peer influence and network externalities. 


\section{$8 \quad$ Marketing Implications}

In the field of marketing strategy, there is a wide range of literature on firstmover advantages (see Kerin et al. 1992 for an extensive overview). From an industrial organization perspective, the first-mover advantage can be explained by the barriers-to-entry concept. Von Weizsäcker $(1980,400)$ describes a barrier to entry as a "cost of producing which must be borne by a firm which seeks to enter an industry but is not borne by firms already in the industry". In our particular example of a network market, the barrier to entry is less a cost of production, and more an additional cost of distribution. The incumbent or early mover has the benefit of a larger network size, resulting in peer influence in favor of her product. To enter the market successfully, the follower must find a way to reduce this peer influence. Possible strategies from the literature on network economics range from establishing compatibility with the incumbent's product (Besen/Farrel 1994) or offering a guarantee of satisfaction or a price discount (Liebowitz/Margolis 1994). A common factor in these strategies is that they all try to reduce the degree or the impact of the incumbent's installed-base-advantage.

However, since it is the peer-effect and not the installed-base-effect of network externalities that influences the adoption decision in our case, another approach might also produce good results. A good strategy might be to create favorable conditions that increase peer influence, thus stimulating the adoption of a product such as consumption in public, commercials embedding peers ${ }^{8}$ or giving early adopters an incentive to attract new customers. Another strategy might be to concentrate the efforts of market entry on socially proximate groups such as, e.g., ethnic minorities. Peer influence

\footnotetext{
${ }^{8}$ Several marketing scholars analyze the joint effects of advertising and peers and find that the perception of the product depends significantly on that the advertisement shows peers consuming the product (e.g., Pechmann/Knight 2002; Andrews et al. 2005).
} 
should have a greater impact here than among less socially proximate groups. 
Appendix

Insert tables A1, A2, A3, A4 and A5 about here. 


\section{References}

Bauer, Raymond A. (1960), Consumer Behaviour as Risk Taking, in: Hancock, R. (ed.): Proceedings of the 43th Conference of the American Marketing Association, 389-98.

Bearden, William O./Etzel, Michael J. (1982), Reference Group Influence on Product and Brand Purchase Decisions, Journal of Consumer Research 9, 183-94.

Besen, Stanley M./Farrel, Joseph (1994), Choosing How to Compete: Strategies and Tactics in Standardization, Journal of Economic Perspectives $8,117-31$.

Bruner, Gordon C./Hensel, Paul J. (eds.), Marketing Scales Handbook: A Compilation of Multi-Item Measures, Chicago: American Marketing Association. 1992.

Brynjolfsson, Eric/Kemerer, Chris F. (1996), Network Externalities in Microcomputer Software: An Econometric Analysis of the Spreadsheet Market, Management Science 42, 1627-48.

Bass, Frank M. (1969), A New Product Growth Model for Consumer Durables, Management Science 13, 215-27.

Chatterjee, Rabikar/Eliashberg, Jehoshua (1990), The Innovation Diffusion Process in a Heterogeneous Population: A Micromodeling Approach, Management Science 36, 1057-79.

Childers, Terry L./Rao, Akshay, R. Rao (1992), The Influence of Familial and Peer-based Reference Groups on Consumer Decisions, Journal of Consumer Research 19, 198-211.

Cialdini, Robert B./Trost, Melanie R. (1998), Social Influence: Social Norms, Conformity, and Compliance, in D. T. Gibert/ G. Lindzey (ed.), 
The Handbook of Social Psychology 2, New York, IV: McGraw-Hill, 15192.

Clement, Michel (2000), Interaktives Fernsehen - Analyse und Prognose seiner Nutzung, Wiesbaden: Deutscher Universitätsverlag.

Coleman, James S./Katz, Elihu/Menzel, Herbert (1966), Medical Innovation, A Diffusion Study, New York: Bobbs-Merrill.

David, Paul A. (1985), Clio and the Economics of QWERTY, American Economic Review 75, 332-7.

Dickerson, Mary D./Gentry, James W. (1983), Characteristics of Adopters and Non-Adopters of Home-Computers, Journal of Consumer Research $10,225-35$.

Economides, Nicholas (1996), The Economics of Networks, International Journal of Industrial Organization 14, 673-99.

Falk, Armin/Ichino, Andrea (2006), Clean Evidence on Peer Effects, Journal of Labour Economics 24, 39-57.

Farrel, Joseph/Saloner, Garth (1986), Installed Base and Compatibility, American Economic Review 76, 70-83.

Gandal, Neil (1994), Hedonic Price Indexes for Spreadsheets and an Empirical Test for Network-Externalities, Rand Journal of Economics 25, 16070.

Griliches, Zvi (1957), Hybrid Corn: An Exploration in the Economics of Technological Change, Econometrica 48, 501-22.

Grinter, Rebecca E./Palen, L. (2002), Instant Messaging in Teen Life, ACM 2002 Conference on Computer Supported Cooperative Work (CSCW). 
Halebsky, Mark A. (1987), Adolescent Alcohol and Substance Abuse: Parent and Peer Effects, Adolescence 22, 661-7.

Isaacs, E./Walendowski, S./Whittaker, S./Schiano, D. J./Kamm, C. (2002), The Character, Functions, and Styles of Instant Messaging in the Workplace, ACM 2002 Conference on Computer Supported Cooperative Work (CSCW).

Jenkins, Stephen P. (1995), Easy Estimation Methods for Discrete-Time Duration Models, Oxford Bulletin of Economics and Statistics 57, 129-38.

Kandel, Eugene/Lazear, Edward P. (1992), Peer Pressure and Partnerships, Journal of Political Economy 100, 801-17.

Katz, Michael L./Shapiro, Carl (1985), Network Externalities, Competition and Compatibility, American Economic Review 75, 424-40.

Katz, Michael L./Shapiro, Carl (1986), Technology Adoption in the Presence of Network Externalities, Journal of Political Economy 94, 822-41.

Katz, Michael L./Shapiro, Carl (1992), Product Introduction with Network Externalities, The Journal of Industrial Economics 40, 55-83.

Kern, Roger A./Varadarajan, P. Rajan/Peterson, Robert A. (1992), FirstMover Advantage: A Synthesis, Conceptual Framework, and Research Propositions, Journal of Marketing 56, 33-52.

Kim, Hee-Su./Kwon, Namhoon (2003), The Advantage of Network Size in Acquiring New Subscribers: A Conditional Logit Analysis of the Korean Mobile Telephony Market, Information Economics and Policy 15, 17-33.

Köllinger, Philipp (2003), Internetnutzung in Deutschland: nach Boom nun langsamer Anstieg erwarten, Wochenbericht des DIW Berlin 70, 477-83. 
Liebowitz, Stan J./Margolis, Stephen E. (1990), The Fable of the Keys, Journal of Law and Economics 33, 1-23.

Liebowitz, Stan J./Margolis, Stephen E. (1994), Network Externality: An Uncommon Tragedy, Journal of Economic Perspectives 8, 133-50.

Litfin, Thorsten (2000), Adoptionsfaktoren - Empirische Analyse am Beispiel eines innovativen Telekommunikationsdienstes, Wiesbaden: Deutscher Universitätsverlag.

Luo, Xueming (2005), How Does Shopping with Others Influence Impulsive Purchasing?, Journal of Consumer Psychology 15, 228-94.

Mahajan, Vijay/Muller, Eitan/Bass, Frank M. (1990), New Product Diffusion Models in Marketing: A Review and Directions for Research, Journal of Marketing 54, 1-26.

Mangleburg, Tamara F./ Doney, Patricia M./Bristol, Terry (2004), Shopping with Friends and Teens' Susceptibility to Peer Influence, Journal of Retailing 80, 101-16.

Melby, Janet M./Conger, Rand D./Conger, Katharine J./Lorenz, Frederick O (1993), Effects of Parental Behaviour on Tobacco Use by Young Male Adolescents, Journal of Marriage and the Family 55, 439-54.

Nardi, B. A./Whittaker, S./Brandner, E. (2000), Interaction and Outeraction: Instant Messaging in Action, ACM 2000 Conference on Computer Supported Cooperative Work (CSCW).

Pechmann, Cornelia/Knight, Susan J. (2002), An Experimental Investigation of the Joint Effects of Advertising and Peers on Adolescents' Beliefs and Intentions about Cigarette Consumption, Journal of Consumer Research 29, 5-19. 
Rogers, Everett M. (2003), Diffusion of Innovations, New York: The Free Press.

Saloner, Garth/Shepard, Andrea (1995), Adoption of Technologies with Network Effects: An Examination of the Adoption of Automated Teller Machines, Rand Journal of Economics 26, 479-501.

Schnell, Rainer/Hill, Paul B./Esser, Elke (2005), Methoden der empirischen Sozialforschung, München: Oldenbourg.

Shiu, Eulynn/Lenhard, Amanda (2004), How Americans use Internet Messaging, Pew Internet \& American Life Project, Washington: Pew Internet $\&$ American Life Project.

Stoneman, Paul (2002), The Economics of Technological Diffusion, Oxford (UK): Blackwell Publishers.

Tanny, S. M./Derzko, N. A. (1988), Innovators and Imitators in Innovation Diffusion Modeling, Journal of Forecasting 7, 225-34.

The Economist (2005), The Internet - The Battle of the Portals, The Economist from October $22^{\text {nd }} 2005,65$.

Von Weizsäcker, Carl C. (1980), A Welfare Analysis of Barriers to Entry, Bell Journal of Economics 11, 399-420.

Van den Bulte, Christophe/Lilien, Gary L. (2001), Medical Innovation Revisited: Social Contagion versus Marketing Effort, American Journal of Sociology 106, 1409-35.

Wooldridge, Jeffrey (2002), Econometric Analysis of Cross Section and Panel Data, Cambridge (MA) and London (UK): The MIT Press. 
Figure 1: Conceptual Framework

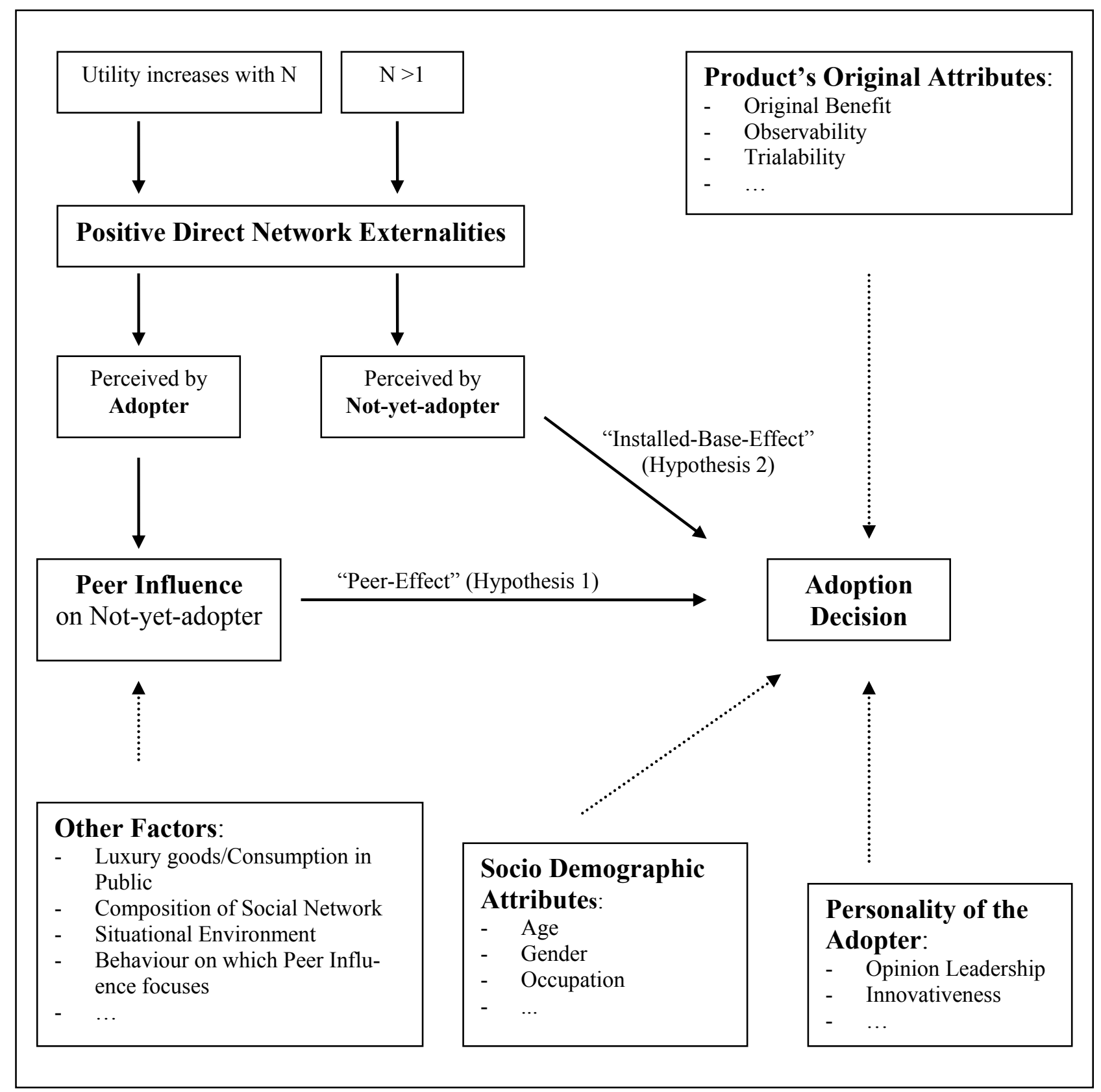


Table 1: Construct Installed Base

\begin{tabular}{|l|l|l|}
\hline Item & Statement & Scale \\
\hline 1 & The diffusion of Instant Messaging among my friends in- & 6-point \\
& creased (would increase) my personal value of the Instant & Likert \\
& Messenger. & Scale \\
\hline
\end{tabular}

Table 2: Construct Peer Influence

\begin{tabular}{|l|l|l|}
\hline Item & Statement & Scale \\
\hline 1 & I was (am) inspired out of my social network to register with & 6-point \\
& the Instant Messenger. & Likert \\
& & Scale \\
\hline
\end{tabular}


Table 3: Random Effects Hazard Rate Regression Results

\begin{tabular}{|c|c|c|}
\hline \multicolumn{3}{|c|}{ Dependent Variable: Adoption Status in Year $t$} \\
\hline Independent Variables & Coefficient & Standard Error \\
\hline DURAT2 & -0.094 & 0.433 \\
\hline DURAT3 & $1.189 * *$ & 0.391 \\
\hline DURAT4 & $2.168 * * *$ & 0.484 \\
\hline DURAT5 & $2.616 * * *$ & 0.614 \\
\hline DURAT6 & $2.666 * * *$ & 0.744 \\
\hline DURAT7 & $2.917 * * *$ & 0.864 \\
\hline DURAT8 & $3.308 * * *$ & 0.978 \\
\hline DURAT9 & $3.577 * * *$ & 1.077 \\
\hline DURAT10 & 0.652 & 1.470 \\
\hline INSTALLED BASE & -0.097 & 0.070 \\
\hline PEER INFLUENCE & $0.198 * *$ & 0.063 \\
\hline RISK & $-0.410 * * *$ & 0.126 \\
\hline TRIALABILITY & $0.228 *$ & 0.110 \\
\hline INNOVATIVENESS & $0.325 * *$ & 0.115 \\
\hline ORIGINAL BENEFIT & 0.106 & 0.086 \\
\hline MALE & 0.203 & 0.170 \\
\hline AGE & $-0.026^{\dagger}$ & 0.015 \\
\hline OPINION LEADERSHIP & 0.092 & 0.069 \\
\hline $\begin{array}{l}\text { INTERNET- } \\
\text { APPLICATIONS } 1\end{array}$ & $1.161 * *$ & 0.439 \\
\hline $\begin{array}{l}\text { INTERNET- } \\
\text { APPLICATIONS } 2\end{array}$ & 0.184 & 0.275 \\
\hline CONSTANT & $-5.495 * * *$ & 1.207 \\
\hline $\begin{array}{l}\text { Number of participants } \\
\text { Number of observations } \\
\text { Observations per group } \\
\text { Min. } \\
\text { Avg. } \\
\text { Max. }\end{array}$ & $\begin{array}{l}370 \\
2,362 \\
1 \\
6.4 \\
10\end{array}$ & \\
\hline $\begin{array}{l}\text { Minus log likelihood } \\
\text { Wald chi } \\
\text { Likelihood-ratio-test }\end{array}$ & $\begin{array}{l}679.89 \\
57.74 \\
p<0.001\end{array}$ & \\
\hline
\end{tabular}


Likelihood-ratio-test of rho $=0$ is not rejected on a conventional level $(\mathrm{p}=0.471)$.

Note: Asterisks indicate that coefficient is significantly different form zero at the 10 percent $\left({ }^{\dagger}\right), 5$ percent $\left(^{*}\right), 1$ percent $(* *)$, or 0.1 percent $(* * *)$ level. 
Table A1: Description of Sample

\section{Sample Composition}

Number of Persons Asked: 470

Final Sample: 370

Adopter/Non-Adopter: Adopter (283); Non-Adopter (87)

Age: Median (25); Mode (25); Min. (14); Max. (70); Mean (27.69); SD (6.98)

Gender: Male (259); Female (111)

Occupation: $71.4 \%$ are students.

Note: We also asked about the adoption of online banking. As many of the respondents were not able to answer questions about Instant Messaging, the sample size is reduced from 470 to 370 participants. 


\begin{tabular}{|c|c|c|c|c|c|c|c|c|c|c|c|c|}
\hline & & 1 & 2 & 3 & 4 & 5 & 6 & 7 & 8 & 9 & 10 & 11 \\
\hline 1 & INSTALLED BASE & & $.270 * *$ & $-.062 * *$ & $.199 * *$ & $.224 * *$ & $.303 * *$ & $.066^{* *}$ & $-.276^{* *}$ & $.158^{* *}$ & $.185^{* *}$ & $.111^{* *}$ \\
\hline 2 & PEER INFLUENCE & $.270 * *$ & & $-.200 * *$ & $.265 * *$ & $.196^{* *}$ & $.395 * *$ & $-.045^{*}$ & $-.217 * *$ & $.057 * *$ & $.333 * *$ & $.119 * *$ \\
\hline 3 & RISK & $-.062 * *$ & $-.200 * *$ & & $-.133 * *$ & $-.055 * *$ & $-.233 * *$ & $-.046^{*}$ & $.162 * *$ & $-.047 *$ & $-.333 * *$ & $-.119 * *$ \\
\hline 4 & TRIALABILITY & $.199 * *$ & $.265 * *$ & $-.133 * *$ & & $.141 * *$ & $.382 * *$ & .032 & $-.272 * *$ & .021 & $.215 * *$ & .030 \\
\hline 5 & INNOVATIVENESS & $.224 * *$ & $.196 * *$ & $-.055 * *$ & $.141 * *$ & & $.297 * *$ & $.123 * *$ & $-.138 * *$ & $.103 * *$ & $.283 * *$ & $.250 * *$ \\
\hline 6 & ORIG.BENEFIT & $.303 * *$ & $.395 * *$ & $-.233 * *$ & $.382 * *$ & $.297 * *$ & & $-.142 * *$ & $-.343 * *$ & $.115 * *$ & $.289 * *$ & $.159 * *$ \\
\hline 7 & MALE & $.066 * *$ & $-.045^{*}$ & $-.046^{*}$ & .032 & $.123 * *$ & $-.142 * *$ & & $.135 * *$ & $.138 * *$ & $.224 * *$ & $.162 * *$ \\
\hline 8 & AGE & $-.276 * *$ & $-.217 * *$ & $.162 * *$ & $-.272 * *$ & $-.138 * *$ & $-.343 * *$ & $.135 * *$ & & -.000 & $-.260 * *$ & .006 \\
\hline 9 & OP. LEADERSHIP & $.158 * *$ & $.057 * *$ & $-.047 *$ & .021 & $.103 * *$ & $.115^{* *}$ & $.138 * *$ & -.000 & & $.185^{* *}$ & $.190 * *$ \\
\hline 10 & INTERNETAPPL1 & $.185 * *$ & $.333 * *$ & $-.333 * *$ & $.215 * *$ & $.283 * *$ & $.289 * *$ & $.224 * *$ & $-.260 * *$ & $.185 * *$ & & $.280 * *$ \\
\hline 11 & INTERNETAPPL2 & $.111 * *$ & $.119 * *$ & $-.119 * *$ & .030 & $.250 * *$ & $.159 * *$ & $.162 * *$ & .006 & $.190 * *$ & $.280 * *$ & \\
\hline
\end{tabular}

$\mathrm{N}: 2,362$

** The correlation is significant on a 1 percent level.

* The correlation is significant on a 5 percent level. 
Table A3: Descriptive Statistics

\begin{tabular}{|c|c|c|c|c|c|}
\hline \multirow[t]{2}{*}{ Variable } & \multicolumn{2}{|c|}{ Mean (SD) } & \multirow{2}{*}{$\begin{array}{l}\text { p-value } \\
\text { (test for equality of } \\
\text { means) }\end{array}$} & \multirow[t]{2}{*}{ Min. } & \multirow[t]{2}{*}{ Max. } \\
\hline & Adopter & Non-Adopter & & & \\
\hline INSTALLED BASE & $4.24(1.54)$ & $3.80(1.58)$ & 0.024 & 1 & 6 \\
\hline PEER INFLUENCE & $3.81(1.61)$ & $1.94(1.21)$ & 0.000 & 1 & 6 \\
\hline RISK* & $2.67(1.03)$ & $3.97(1.10)$ & 0.000 & 1 & 6 \\
\hline TRIALABILITY & $5.09(0.85)$ & $4.16(1.31)$ & 0.000 & 1 & 6 \\
\hline INNOVATIVENESS & $2.18(1.35)$ & $1.47(0.76)$ & 0.000 & 1 & 6 \\
\hline ORIGINAL BENEFIT* & $4.31(0.97)$ & $3.16(1.01)$ & 0.000 & 1 & 6 \\
\hline MALE & $0.71(0.45)$ & $0.67(0.47)$ & 0.439 & 0 & 1 \\
\hline $\mathrm{AGE}$ & $24.51(5.59)$ & $29.54(9.31)$ & 0.000 & 14 & 70 \\
\hline OPINION LEADERSHIP* & $3.72(1.24)$ & $3.51(1.03)$ & 0.148 & 1 & 6 \\
\hline $\begin{array}{l}\text { INTERNET- } \\
\text { APPLICATIONS } 1 *\end{array}$ & $0.46(0.30)$ & $0.18(0.21)$ & 0.000 & 0 & 1 \\
\hline $\begin{array}{l}\text { INTERNET- } \\
\text { APPLICATIONS } 2 *\end{array}$ & $0.18(0.31)$ & $0.07(0.20)$ & 0.003 & 0 & 1 \\
\hline
\end{tabular}

Notes: Asterisks indicate that we construct the variable by taking the mean of several single items (table A4); $\mathrm{N}: 370$ 
Table A4: Operationalization of Constructs

\begin{tabular}{|c|c|c|}
\hline \multicolumn{3}{|c|}{ Construct INSTALLED BASE } \\
\hline Item & Statement & Mean (SD) \\
\hline 1 & $\begin{array}{l}\text { The diffusion of Instant Messaging among my friends in- } \\
\text { creased my personal value of the Instant Messenger. }\end{array}$ & $4.12(1.59)$ \\
\hline \multicolumn{3}{|c|}{ Construct PEER INFLUENCE } \\
\hline Item & Statement & Mean (SD) \\
\hline 1 & $\begin{array}{l}\text { I was inspired out of my social network to register with the } \\
\text { Instant Messenger. }\end{array}$ & $3.35(1.73)$ \\
\hline \multicolumn{3}{|c|}{ Construct RISK $^{2}$} \\
\hline Item & Statement & Mean (SD) \\
\hline 1 & I was afraid to infect my computer with a virus. & $2.89(1.64)$ \\
\hline 2 & $\begin{array}{l}\text { Regarding the registration, I worried about problems of data } \\
\text { protection. }\end{array}$ & $3.19(1.55)$ \\
\hline 3 & $\begin{array}{l}\text { I was afraid that the Instant Messenger could distract me } \\
\text { from doing other things. }\end{array}$ & $2.81(1.58)$ \\
\hline \multicolumn{3}{|c|}{ Cronbach $\alpha=0.60 ;$ Explained Variance $=56.43 \%$} \\
\hline \multicolumn{3}{|c|}{ Construct TRIALABILITY } \\
\hline Item & Statement & Mean (SD) \\
\hline 1 & Without great effort, I was able to try the Instant Messenger. & $4.87(1.08)$ \\
\hline \multicolumn{3}{|c|}{ Construct INNOVATIVENESS (of Adopter) } \\
\hline Item & Statement & Mean (SD) \\
\hline 1 & I wanted to be among the first who register. & $2.02(1.29)$ \\
\hline \multicolumn{3}{|c|}{ Construct ORIGINAL BENEFIT (ORIG.BENEFIT) ${ }^{2}$} \\
\hline Item & Statement & Mean (SD) \\
\hline 1 & $\begin{array}{l}\text { Compared to other modes of communication, the Instant } \\
\text { Messenger was more comfortable. }\end{array}$ & $3.64(1.50)$ \\
\hline
\end{tabular}




\begin{tabular}{|c|c|c|}
\hline 2 & $\begin{array}{l}\text { Via the Instant Messenger, I was able to communicate faster } \\
\text { than via email. }\end{array}$ & $4.84(1.39)$ \\
\hline 3 & $\begin{array}{l}\text { The benefits of a registration with the Instant Messenger } \\
\text { were obvious. }\end{array}$ & $3.72(1.41)$ \\
\hline \multicolumn{3}{|c|}{ Cronbach $\boldsymbol{\alpha}=0.631 ;$ Explained Variance $=57.38 \%$} \\
\hline \multicolumn{3}{|c|}{ Construct OPINION LEADERSHIP (OP.LEADERSHIP) ${ }^{1,2}$} \\
\hline Item & Statement & Mean (SD) \\
\hline 1 & My friends often come to me for advice. & $3.82(1.35)$ \\
\hline 2 & I often influence the purchase decisions of my friends. & $3.57(1.32)$ \\
\hline 3 & $\begin{array}{l}\text { People come to me more often that I go to them for informa- } \\
\text { tion about new acquisitions. }\end{array}$ & $3.60(1.42)$ \\
\hline \multicolumn{3}{|c|}{ Cronbach $\boldsymbol{\alpha}=0.86 ;$ Explained Variance $=77.5 \%$} \\
\hline \multicolumn{3}{|c|}{ 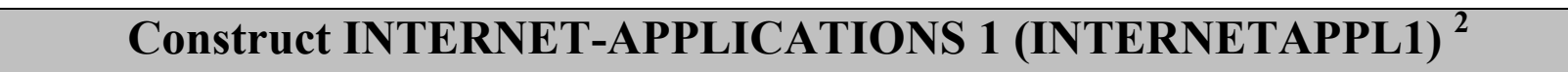 } \\
\hline Item & Statement & Mean (SD) \\
\hline 1 & I send SMS by Internet (yes/no). & $0.45(0.50)$ \\
\hline 2 & I download videos from the Internet (yes/no). & $0.36(0.48)$ \\
\hline 3 & I play online games (yes/no). & $0.30(0.46)$ \\
\hline 4 & I download music from the Internet (yes/no). & $0.53(0.50)$ \\
\hline 5 & I visit newsgroups (yes/no). & $0.28(0.45)$ \\
\hline \multicolumn{3}{|c|}{ Cronbach $\boldsymbol{\alpha}=0.62 ;$ Explained Variance $=41.13 \%$} \\
\hline \multicolumn{3}{|c|}{ Construct INTERNET-APPLICATIONS 2 (INTERNETAPPL2) ${ }^{2}$} \\
\hline Item & Statement & Mean (SD) \\
\hline 1 & I use Internet-telephony (yes/no). & $0.20(0.40)$ \\
\hline 2 & I use a webcam (yes/no). & $0.12(0.33)$ \\
\hline \multicolumn{3}{|c|}{ Cronbach $\boldsymbol{\alpha}=0.55 ;$ Explained Variance $=69.47 \%$} \\
\hline Notes & \multicolumn{2}{|c|}{$\begin{array}{l}{ }^{1} \text { We obtain the scale from a marketing scales handbook, edited by } \\
\text { Bruner/Hensel }(1992,292) \text {. For this scale, Dickerson/Gentry (1983) } \\
\text { report a Cronbach } \alpha \text { of } 0.6 \text {. }\end{array}$} \\
\hline
\end{tabular}


(mean of corresponding single item measures). We report the Cronbach $\alpha$ to demonstrate the degree of the construct's internal consistency.

${ }^{3}$ We construct the variable MALE as a yes/no-question.

${ }^{4}$ Adopters received the questions in past tense. Non-adopters received the questions in present tense. 
Table A5: Random Effects Hazard Rate Regression Results (Online Banking)

\begin{tabular}{|c|c|c|}
\hline \multicolumn{3}{|c|}{ Dependent Variable: Adoption Status in Year $t$} \\
\hline Independent Variables & Coefficient & Standard Error \\
\hline DURAT2 & $-0.993 *$ & 0.453 \\
\hline DURAT3 & 0.484 & 0.319 \\
\hline DURAT4 & $0.913 * *$ & 0.312 \\
\hline DURAT5 & $1.984 * * *$ & 0.297 \\
\hline DURAT6 & $2.104 * * *$ & 0.318 \\
\hline DURAT7 & $2.728 * * *$ & 0.334 \\
\hline DURAT8 & $3.251 * * *$ & 0.360 \\
\hline DURAT9 & $3.472 * * *$ & 0.399 \\
\hline DURAT10 & -0.039 & 1.066 \\
\hline INSTALLED BASE & -0.061 & 0.092 \\
\hline PEER INFLUENCE & 0.037 & 0.062 \\
\hline RISK & $-0.273^{* * *}$ & 0.050 \\
\hline TRIALABILITY & 0.022 & 0.057 \\
\hline ORIGINAL BENEFIT & $0.612 * * *$ & 0.101 \\
\hline COSTS & 0.065 & 0.043 \\
\hline MALE & $0.626 * * *$ & 0.168 \\
\hline AGE & $0.025^{* *}$ & 0.005 \\
\hline \begin{tabular}{|l} 
CLERK \\
\end{tabular} & $0.459 *$ & 0.187 \\
\hline OPINION LEADERSHIP & $0.182 * *$ & 0.065 \\
\hline $\begin{array}{l}\text { INTERNET- } \\
\text { APPLICATIONS } 1\end{array}$ & $1.146 * *$ & 0.276 \\
\hline $\begin{array}{l}\text { INTERNET- } \\
\text { APPLICATIONS } 2\end{array}$ & 0.370 & 0.281 \\
\hline CONSTANT & $-7.874 * * *$ & 0.779 \\
\hline $\begin{array}{l}\text { Number of participants } \\
\text { Number of observations } \\
\text { Observations per group }\end{array}$ & $\begin{array}{l}434 \\
2,918\end{array}$ & \\
\hline $\begin{array}{c}\text { Min. } \\
\text { Avg. } \\
\text { Max. }\end{array}$ & $\begin{array}{l}1 \\
6.7 \\
10\end{array}$ & \\
\hline Minus log likelihood & 840.13 & \\
\hline
\end{tabular}




$\begin{array}{ll}\text { Wald chi }^{\mathbf{2}} \text { (20) } & 188.14 \\ \text { Likelihood-ratio-test } & \mathrm{p}<0.001\end{array}$
$\begin{aligned} & \text { Likelihood-ratio-test of rho }= \\ & (\mathrm{p}=0.11) .\end{aligned}$

Note: Asterisks indicate that coefficient is significantly different form zero at the 10 percent $\left({ }^{\dagger}\right), 5$ percent $(*), 1$ percent $(* *)$, or 0.1 percent $(* * *)$ level. 


\section{Publications in the ERIM Report Series Research* in Management}

\section{ERIM Research Program: "Organizing for Performance"}

2007

Leadership Behaviour and Upward Feedback: Findings From a Longitudinal Intervention

Dirk van Dierendonck, Clare Haynes, Carol Borrill and Chris Stride

ERS-2007-003-ORG

http://hdl.handle.net/1765/8579

The Clean Development Mechanism: Institutionalizing New Power Relations

Bettina B.F. Wittneben

ERS-2007-004-ORG

http://hdl.handle.net/1765/8582

How Today's Consumers Perceive Tomorrow's Smart Products

Serge A. Rijsdijk and Erik Jan Hultink

ERS-2007-005-ORG

http://hdl.handle.net/1765/8984

Product Intelligence: Its Conceptualization, Measurement and Impact on Consumer Satisfaction

Serge A. Rijsdijk, Erik Jan Hultink and Adamantios Diamantopoulos

ERS-2007-006-ORG

http://hdl.handle.net/1765/8580

Testing the Strength of the Iron Cage: A Meta-Analysis of Neo-Institutional Theory

Pursey P.M.A.R. Heugens and Michel Lander

ERS-2007-007-ORG

http://hdl.handle.net/1765/8581

Export Orientation among New Ventures and Economic Growth

S. Jolanda A. Hessels and André van Stel

ERS-2007-008-ORG

http://hdl.handle.net/1765/8583

Allocation and Productivity of Time in New Ventures of Female and Male Entrepreneurs

Ingrid Verheul, Martin Carree and Roy Thurik

ERS-2007-009-ORG

http://hdl.handle.net/1765/8989

Cooperating if one's Goals are Collective-Based: Social Identification Effects in Social Dilemmas as a Function of Goal-Transformation David De Cremer, Daan van Knippenberg, Eric van Dijk and Esther van Leeuwen

ERS-2007-010-ORG

http://hdl.handle.net/1765/9041

Unfit to Learn? How Long View Organizations Adapt to Environmental Jolts

Pursey P. M. A. R. Heugens and Stelios C. Zyglidopoulos

ERS-2007-014-ORG

http://hdl.handle.net/1765/9404

Going, Going, Gone. Innovation and Exit in Manufacturing Firms

Elena Cefis and Orietta Marsili

ERS-2007-015-ORG

http://hdl.handle.net/1765/9732 
High in the Hierarchy: How Vertical Location and Judgments of Leaders' Power are Interrelated

Steffen R. Giessner and Thomas W. Schubert

ERS-2007-021-ORG

http://hdl.handle.net/1765/9727

Contracts to Communities: a Processual Model of Organizational Virtue

Pursey P.M.A.R. Heugens, Muel Kaptein and J. van Oosterhout

ERS-2007-023-ORG

http://hdl.handle.net/1765/9728

Why Are Some Entrepreneurs More Innovative Than Others?

Philipp Koellinger

ERS-2007-024-ORG

http://hdl.handle.net/1765/9730

Stimulating Strategically Aligned Behaviour Among Employees

Cees B. M. van Riel, Guido Berens and Majorie Dijkstra

ERS-2007-029-ORG

http://hdl.handle.net/1765/10067

The Effectiveness of Business Codes: A Critical Examination of Existing Studies and the Development of an Integrated Research Model

Muel Kaptein and Mark Schwartz

ERS-2007-030-ORG

http://hdl.handle.net/1765/10150

Knowledge Spillovers and Entrepreneurs' Export Orientation

Dirk De Clercq, Jolanda Hessels and André van Stel

ERS-2007-038-ORG

http://hdl.handle.net/1765/10178

Silicon Valley in the Polder? Entrepreneurial Dynamics, Virtuous Clusters and Vicious Firms in the Netherlands and Flanders Willem Hulsink, Harry Bouwman and Tom Elfring

ERS-2007-048-ORG

http://hdl.handle.net/1765/10459

An Incomplete Contracting Model of Governance Structure Variety in Franchising

George Hendrikse and Tao Jiang

ERS-2007-049-ORG

http://hdl.handle.net/1765/10462

On the Evolution of Product Portfolio Coherence of Cooperatives versus Corporations: An Agent-Based Analysis of the Single Origin Constraint

George Hendrikse and Ruud Smit

ERS-2007-055-ORG

Greenfield or Acquisition Entry: A Review of the Empirical Foreign Establishment Mode Literature Arjen H.L. Slangen and Jean-François Hennart

ERS-2007-059-ORG

Do Multinationals Really Prefer to Enter Culturally-Distant Countries Through Greenfields Rather than Through Acquisitions? The Role of Parent Experience and Subsidiary Autonomy

Arjen H.L. Slangen and Jean-François Hennart

ERS-2007-060-ORG 
The Financial Centres of Shanghai and Hong Kong: Competition or Complementarity? Bas Karreman and Bert van der Knaap

ERS-2007-062-ORG

Peer Influence in Network Markets: An Empirical Investigation Jörn H. Block and Philipp Köllinger

ERS-2007-063-ORG

* A complete overview of the ERIM Report Series Research in Management: https://ep.eur.n//handle/1765/1

ERIM Research Programs:

LIS Business Processes, Logistics and Information Systems

ORG Organizing for Performance

MKT Marketing

F\&A Finance and Accounting

STR Strategy and Entrepreneurship 